\title{
Achiever of Higher Self: A Humanistic Study of Celie's Character in the Novel, Color Purple
}

\author{
Qurratulain Sardar ${ }^{1} \&$ Rafique A. Memon ${ }^{1}$ \\ ${ }^{1}$ Institute of English Language \& Literature, University of Sindh, Jamshoro, Pakistan \\ Correspondence: Qurratulain Sardar, Institute of English Language \& Literature, University of Sindh, Jamshoro, \\ Pakistan. E-mail: qurratulain.sardar@scholars.usindh.edu.pk
}

Received: August 8, 2019

Accepted: September 25, 2019 Online Published: November 12, 2019

doi:10.5539/ijel.v9n6p373

URL: https://doi.org/10.5539/ijel.v9n6p373

\begin{abstract}
A. Maslow in his book Motivation and Personality (1954) presents the five-stage hierarchy Model, emphasizes on the fulfilment of needs to achieving higher self. Based on textual analysis, the study demonstrates how the protagonist Celie, from the novel Color Purple written by Alice Walker, follows the gratification of needs in edict to connect the higher self. The evolution of character's personality has been appraised thoroughly at each level, gives an equal attentive of new visions into her conduct and relationships with other characters. The Colloquial African-American dialect of the text is taken metaphorically, formulates the scarcity of needs created by external milieu. It is inimitably distinguished to identify the one of the major forces after her unusual, capricious and incoherent behaviors are usual social human drives.
\end{abstract}

Keywords: humanist, Celie, Maslow, motivation, personality, hierarchy

\section{Introduction}

Abraham Maslow baptizes 'self-actualization,' the topmost level of hierarchy of needs theory as an integral part of human motivation. In his book, Motivation and Personality (1954), he emphasizes human motivation must start from the bottom of the hierarchy and move onwards. First comes biological and physiological, second safety, third comes belonging and love needs, and the fourth level in the hierarchy associates with Esteem needs, respectively. He asserts typically people embrace Maslow's hierarchy order for the satisfaction of needs. Maslow constrains the highest purpose of man's motivation to meet with the needs implemented positive changes in his behavior. But a lower need preferably satisfied for the emergence of another. Following need possibly appears in terms of degrees prior the lower need wholly fulfilled. Moreover, the lower need could emerge later without real anticipated aspects of need.

Maslow hierarchy model studies literary characters and their motivational aspects through psychological means. Mostly, Freud's theory of human psychology has been prioritized for literary analysis and other models for human observance has been flouted. Through Maslow's hierarchy model literary characters explain intensively.

Walker unveils different aspects of human psychology through characters. Color Purple provides a great possibility to appreciate characters. Writer modifies and embellishing Celie's behavior throughout her journey into different directions prompts philosophical insights. The fascinating knowing of inspiration and motivation following her peculiar behavior are simply driven through common human needs as given by Maslow's hierarchy Model.

The novel is a narrative of a young Black girl Celie, was born into poverty and loneliness. She was assaulted by her father "Pa". She later came to know him as her false-father. The title Color Purple emphasizes the ubiquitous relationship between 'Man and the Nature'. The 'purple' color according to Walker, 'Color is always a surprise but is everywhere in nature.' Walker displays the exploration of a person of being a unique part of the Nature and the world (Walker, 1983). The language of the text plays an essential part in the formation of the ideas of scarcity of needs created by external milieu. Celie being an ill-educated creature, knows little about language. Writer has artistically framed the character's mind through simple meek words. In a colloquial manner the narrative speaks African-American cultural life of inadequate provision. The present study has extracted data by using purposeful technique. The next section will discuss the established researches on the novel and theory. 


\section{Literature Review}

Mawaddah (2010) in The Alchemist, studied the protagonist Santiago by applying Maslow's theory of human needs. The study proffered how Santiago's needs get fulfilled views from Maslow's theory. The study has extensively examined Santiago's character at each level of hierarchy. However, the inquiry has failed to advocate the connection between theory and the selected data inventively. At the top most level self-actualization of hierarchy model, seeking "peak experiences" is a vital content. The study has unheeded the peek experiences of Santiago's excursion, confined "self-actualizing characteristics" merely "to become actualized what he is potentially" (Mawaddah, 2010, p. 38). Maslow designates a "peek experience" as, "The feeling of great ecstasy of wonder and awe, the loss of placing in time and space with, finally, the conviction something extremely important and valuable had happened, so the subject is to some extent transformed and strengthened" (Maslow, 1954, p. 216). Maslow's self-actualization is tremendously dominated phase of motivation theory and requires profound attention dealing critically over literary texts.

Svensson (2013) appraised Frankenstein as a psychoanalytical reading of Mary Shelley's journey into the subconscious of a gifted mind. The research delved into Maslow's theory to explore how a formalist approach dissects psychoanalysis. Both Freudian and Maslowian approaches applied to recognize the creative "chaos" behind the Shelley's gothic horror story. The study has also attempted to define the meaning behind the narrative structure. The Freudian model (the ego/Id) and Maslow theory collectively discovered the mystery of mind for the 'psychoanalytical interpretation of symbolism' within Frankenstein.

Wills (2008) applied humanistic methodology for the similar investigation of Agatha Christie's two-story accumulations. The both principle characters, Mr. Parker and Miss Jane Marple, addressed the humanistic truth in the content by utilizing the Maslow Hierarchy Model. The information composed with classifications to engrossed results. The results declared both characters have incorporated same attributes through each level. However humanistic perspective has discriminated both characters on their accomplishment of necessities. Mr. Parker's is higher on accomplishment of necessities and Miss Marple works on inferior needs. Maslow accepts individuals procure their needs as indicated by their condition and social standing. The characters have distinctive social positions and disparate circumstances to proffer towards needs gratification.

Proudfit (1991) examined Color Purple in the light of the Psychologist D.W Winnicot's theory of extravagant of the adult advancement stages, accompanied ideas of the "good-enough mother", a "true self" and a "false self". The investigation considered a mother-girl bond and related Winnicot's concept of good-mother to the protagonist Celie's earliest stages arrange. The study related the mother girl bond rightly to Celie "mother of infancy" and other female characters in the novel (e.g, Shug, Neittee, Sofia and Kate). The investigation assessed this female bond empowers Celie. Strengthen Celie from a discouraged denied, physical disregard, assault, maltreatment victim to recommence apprehended progression, proceeds with formative personality growth was halted in outset.

The research content has been associated with the prior stage object relation. The specific stage signifies future improvement in adulthood. However, Walker does never introduce Celie as an infant, she presents her as an adult child. Though, Winnicott's hypothesis of exacting stage improvement pursues a few phases to procure "true self" of the absolute development; from the life of the initial couple of weeks to the half year. Later, a two-year stage leads an infant began to create inward capacities towards a grown-up stage. The study began to check from the first two years of Celie's earliest stages as a total steady condition. The investigation featured the vast majority of the ideas associated with the infant Celie, have overlooked the present situation and its impact on her. In the development of theory, the genuine story has been limited and decreased.

The academic community has sufficiently described various purports sketched on different characters. And explicitly formulates how borrowed theories are actualized on fiction to comprehend human personality and nature. The next section will illuminate about research process and methodology.

\section{Methodology}

\subsection{Textual Analysis}

The study is based on the close reading of the text. "Texts are used to communicate some ideas/massages to the reader. The purpose of the textual analysis is to find out who says what, to whom, why, to what extend and with what extent and with what effect" (Laswell, 1992).

\subsection{Analysis Process}

The selected character has been discussed on each level of the theory by examining her needs. 
The selected Character's motivation has been discussed separately and in connection to others.

\subsection{Research Instrument}

Researchers are the instrument of the present study. By perusing writings altogether comprehended and recognized the ideas cautiously, permits to become familiar with the material profoundly, to ignore false judgments within analysis. At point examination of the related information has been made by the Hierarchy Needs theory. Researchers have categorically portrayed the primary character as the analysis proof of the gratification chain of needs, offered by Maslow, in the related novel.

\section{Analysis}

Color Purple tremulously speaks the mind of a young girl Celie, deprived of knowing her true self. Her passive nature prohibited her to defense surroundings. Celie's character has advanced through different phases. She has extensively embedded to arrant her basic needs for an expeditious progression. The study administers Maslow's theory to analysis the Celie's character. The analysis has been drawn by identifying words, ideas, concepts, feelings and emotions with related to the description, triggers the character towards fulfilment of needs.

\subsection{Physiological Needs and Celie's Character}

Table 1. Physiological needs associate with Celie's motivation

\begin{tabular}{l}
\hline Pa is driven by "sex" as a basic need. \\
Mom is driven by "health" as a basic need. \\
Celie attains "all" physiological needs. \\
\hline
\end{tabular}

The hierarchy of needs model emanates 'sex' in psychological needs. As Maslow's states in the "Motivation and Personality" (1954), "Sex may be studied as a purely physiological need" (Maslow, 1954, p. 44). When Celie's stepfather tries to intimate with mother, she refuses with anger, "can't you see I am already half dead" (Walker, 1983, p. 3). Instead commiserating her, he has shown revengeful attitude. He entices Celie and satisfies himself, "you gonna do what your mummy wouldn't" (Walker, 1983, p. 3). He has repudiated the ailing mother, fighting affliction for (health) as the basic need. Subsequently, Celie has to endure 'Step-Pa's rapacious actions. The scarcity of mom's health inadequate 'Pa's sexual needs. According to Maslow, "It seems impossible to make any list of fundamental psychological needs and the description might depend on one's wish" (Maslow, 1954, p. 39). The infirmities of health needs devastatingly prompted Celie's life.

Celie's step father has directed through scantiness of 'sex' and got demented for need. He has never been fascinated towards Celie before and considered her an "ugly" creature. As Maslow declares, "for the person who is extremely hungry, no other interest but food" (Maslow, 1954, p. 3). Once the basic need is satisfied it is no longer a want. Like hunger, if sex is slaked it becomes unimportant. Celie's Pa behaves normally with wife later, "she happy cause he good to her now" (Maslow, 1954, p. 3). The mother's health has created chaos in Celie's life. Had her mother absorbed sound health, the circumstance in Celie's life would have been different.

\subsection{Safety Needs in Celie's Character}

Table 2. Safety needs associate with Celie's motivation

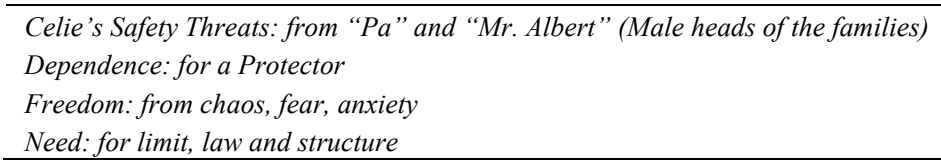

Presumably, Celie has attained all her physiological needs. Here Maslow raises a question, what happened to desires 'when there is plenty of bread and when his belly is chronically filled.' He illustrates 'in this condition higher needs dominated and one the basic needs is satisfied other needs come up" (Walker, 1983, p. 38).

Next level appears Safety needs at the hierarchy. Maslow believes child safety needs preferably concerned more with the orderly world, "injustice, unfairness, or inconsistency in the parents seems to make a child feel anxious and unsafe" (Maslow, 1954, p. 40). Such behavior leads to speculate threaten of an unreliable, unsafe and unpredictable world. However, Writer introduces Celie as a grown-up child. Similarly, an undeniable reality of Celie's life is her safety needs threaten by her own guardian "Pa". Celie has been confronted with an unfamiliar 
occurrence when she is separated shortly from her mother. Maslow establishes parents' role in safety needs mainly under such circumstances, "particularly at such times, the child frantic clinging to his/her parents is eloquent testimony to their roles as protectors (quite apart from their roles as food giver and love givers)" (Maslow, 1940, p. 42).

Though, Celie's normal family system seems to be quite disputable. Consequently, she has never been treated as fortunate adults of the society who satisfy their safety needs through their parents and social support. She feels apprehensive and vulnerable from the desolateness and tyranny of the surroundings.

Celie's destitution for safety needs breeds her concerns for younger sister. She readily supplies protection to Nettie, "I see him looking at my little sister. S he scared, but I say I'll take care you. With God help" (Walker, 1983, p. 5). However, she remains disdained for her-self.

She was tormented and distressed at her wedding day. When Mr. Albert's twelve-year-old son injured Celie's head by pelting stone and blood started to flow. In the redress of this cruel and disgust behavior Mr. Albert just said, "Don't do" (Walker, 1983, p. 80). The insufficient and unsympathetic remarks of Mr. Albert further deteriorated her condition. Ironically, Celie's husband has never become a defender and protector for her. This unsympathetic behavior of husband has evolved deep seclusion. Though in the hierarchy, safety level appears next the physiological supplies, Celie has never received physical and mental endorsement, neither from parents nor from husband. Her protection was being threatened always. Her husband would beat her brutally and inhumanely. Nettie and Kate have counseled her to instigate voice against viciousness of her husband. But she has chosen to remain quiet. She works but never argues. Her voiceless dumb persona proves her futile to others. And her 'only thinking' never brings stability in her personality.

Nettie and Kate have been impotent to understand Celie's situation. That Celie has dependability to the lower needs. The behavior of Nettie and Kate might be considered as the behavior of people who are at their higher level of needs. They are incapable to apprehend that Celie's safety concerns are chief priority. Nettie prompts her to react, Kate scolds to defend herself. But none has assured her stability by holding her ground against the world. Nettie is considered the only blood relation, depends on Celie for safety needs. Result, Nettie has emerged a stable and daring person. Because Celie provides her with safety and care. Though Nettie loves Celie too, but she fails to provide her with protection.

Maslow expresses sometimes this safety need, particularly in some "neurotic adults" turns special appearance, like his or her safety needs often involves in finding a "stranger person with whom he/she may depend" (Maslow, 1954, p. 42). Celie has always perceived Shug as "the most beautiful, stronger person." Celie's safety needs have been constantly disturbed by external threats, as Maslow's theory implies "living near the safety lines." Her safety needs are pivotal to satisfy with someone. Finally, Celie encounters her safety needs through Shug. She has excavated about Mr. Albert ruthless behavior. Shug's response approves her protection needs, “Oh, Miss Celie, ... I won't leave you, until I know Albert won't even think about hitting you" (Walker, 1983, p. 72). Inceptively, Celie has been rescued and released from domestic violence.

\subsection{Love and Belonging Needs in Celie's Character}

Table 3. Belonging needs associated with Celie's motivation

She fantasies Shug for her "doll": As her innocence, has been stolen.
She fantasies Shug for "Olivia": her desire for her children, for her relations.
She fantasies Shug for "mom": her detachment with her mother.

Belonging needs transpire in the hierarchy with the execution of passion, friendships, and love bonding in relations. Celie's personality intensely mirrors the hollowness of her despondent belonging needs. She has miserably received an unaffectionate family bond. Her position in family has merely confined to a custodian for her siblings. Nettie is the only family member, who she shares an affectionate bonding. She precludes Nettie from marrying Mr. Albert "I don't tell her why" (Walker, 1983, p. 7). However, she remains immerses with Nettie about her endurances. The constant emotional repression has caused her unable to trust and appreciate relations.

Having tied to knot with Mr. Albert, her life has confined to a caretaker. Mr. Albert has often beaten her down. 'Once Harpo asked why he beat me', Mr. Albert has readily frowned, "she Stubborn" (Walker, 1983, p. 23). Harpo probes of being stubborn, Celie has felt exhorted otherwise, "how come you his wife, nobody as that" (Walker, 1983, p. 23). In a heedful observance, her position in both families declares scarceness of belongings. 
Celie deeply craves for love and affection. Shug enters and works for Celie's safety needs. Simultaneously, she commences to foster love and belonging needs. Shug has been Celie's first love. She fonds listening, thinking and imaging Shug. Her first encounter has fallen her with cherish, "I feel like once I see her eyes, my feet can let go the spot where they stuck" (Walker, 1983, p. 44). Shug's disposition brings all her lost relations. She reminiscences, "I work on her like a doll or like she Olivia — or like her mama" (Walker, 1983, p. 51).

Her craving for love surrounds these few people. Metaphorically, Mom, Olivia and doll represent her detached belongings. She lost her doll (her childhood), children, mother's love. She recollects memories to mitigate her torn sentients. Celie disgusts Men. She feels repulsion for all the men she has encountered in her life. Her feelings are centered to women only; Mom, Nettie, Olivia and-Shug Avery. "she melts down little and lean back against knees., feel like mama used to do. Or maybe grandma" (Walker, 1983, p. 51).

Shug's phenomenal presence has accomplished Celie's belonging needs. Shug has become her whole world. Her disconnected soul receives all vanishing sounds with Shug. A comparison of Celie's connection brings profound strength for further analysis.

Table 4. Shug's love in contrast with existing relations

\begin{tabular}{l} 
Celie's love for mom $v / s$ Shug \\
Celie's love for Nettie $v / s$ Shug \\
Celie's relationship with God and Shug \\
Celie relation with Mr..... (Albert) v/s Shug \\
\hline
\end{tabular}

She textures her sleeping experience with Shug, "What's it like? A little like sleeping with mama, only I can't remember ever sleeping with her" (Walker, 1983, p. 104). Her desire for mother's love trembling hard with Shug's love. Old neglected wounds resurfacing, and she has scarcely reminisced the deserted relationship with mother. Shug's relationship feels worthier than mother. She moves to Nettie's love, "only sleeping with Nettie never feel this good" (Walker, 1983, p. 104).

Shug's limitless compassion brings profound changes in Celie's personality. The "Only" (sleeping with Nettie) is pointing her assorted relation with Shug. She shares a tender sister bond with Nettie however the warmth for Shug goes beyond measure. Moreover, she has never drawn to Nettie. Ironically the word "Only" shows her relation to the entire world except Shug. "Only" Shug brings joy to her life. She encounters all distorted needs for belonging; mom's love, friendship, well-wisher, protector a whole world in "Shug".

The only acquaintance she addresses to is "God". Her relationship with God has always been a unique part of her entire journey to the Self-Actualization. The sensation and warmth of Shug's love made Celie closer to God, "It feel like heaven is what it feels like" (Walker, 1983, p. 104). Mr. Albert never adores Celie. The marriage was never grounded on love. Therefore, Celie has never shared a spiritual, blissful connection with Mr. Albert. The special bond of adoration and connection, her wants and sentiments made assuaged through Shug's love. Celie meets love needs and stride towards her voyage to secure "self-Actualization".

4.4 Esteem Needs in Celie's Character (Esteem from Others)

Table 5. Esteem needs in Celie's personality

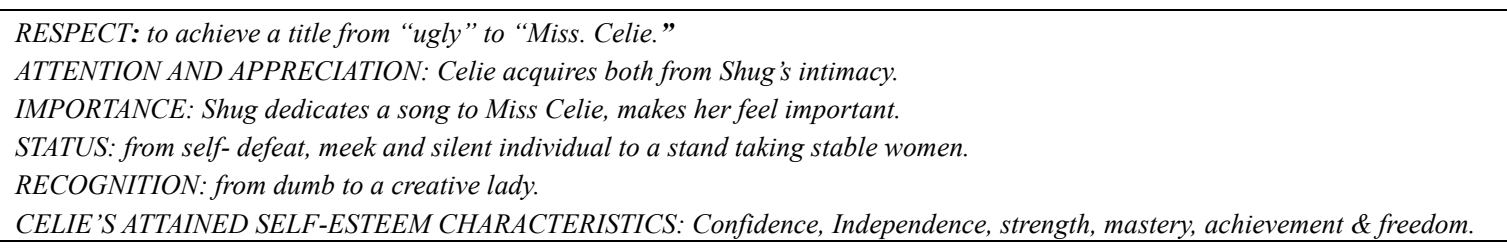

The fourth level of hierarchy allocates to the Esteem Needs. Maslow further disposes into two sets: Self-esteem and Esteem from Others. Maslow considers esteem needs as a prudent level in the excursion to "self-actualization". He alludes, "esteem needs have been disregarded in Freud theory and various psychological theories" (Maslow, 1954, p. 45). In Maslow's theory, Esteem needs are at utmost consideration to understand one's personality. At the point, when Shug calls "Miss. Celie" and devotes a melody her publicly. In response, Celie feels worthier and runs over her confidence. First time she has received the honor and regards from another person. She proclaims the sense of accomplishment and poise "First time somebody made something and name it after me" (Walker, 1983, p. 
70).

When she receives the prestigious acknowledgement, Celie's disintegrated personality has started to become whole again and she relies Shug, "He beat me when you were not here" (Walker, 1983, p. 71).

Further, Shug compliments Celie for being "Virgin" (sense of "dignity" for a girl). That she had considered of being deprived and thought of Nettie having Virginity, "I know she be big..., But me never again" (Walker, 1983, p. 17). But she regains her self-confidence. Incessantly, Shug has contributed and endeavored hard to accomplish her esteem needs. "if you were my wife, I'd cover you up with kisses stead of licks and work hard for you" (Walker, 1983, p. 101).

Maslow elaborates, "satisfaction of the self-esteem needs leads to a feeling of self-confidence, worth strength, capability and adequacy of being useful and necessary in the world" (Maslow, 1983, p. 45). If someone sticks to meet this need, the result will produce inferiority drawbacks and meaninglessness to the victim.

Shug brings her to the value of individuality by showing the power of existence. She has been deprived of self-respect, $\mathrm{Pa}$, and Mr. Albert mitigate her dignity. She has been regarded 'Ugly' throughout. 'Pa' takes her out of school, "you too dumb to keep going, to school" (Walker, 1983, p. 11). Pa's degrading attitude and Mr. Albert deserting behavior have brutally shattered her personality. Maslow's accepts "the most stable and the healthiest self-esteem is based on deserved respect from others" (Maslow, 1954, p. 46). However, Celie informs Shug how ' $\mathrm{Pa}$ ' disrespected her before mom and blamed her for having an illegitimate affair with a boy. And how she was bought by Mr. Albert only for children. Mr. Albert has never stood by her whenever she was beaten by his son. She was only taken for sex purpose. Celie describes his callous, "he came on top of me and fuck and fuck, even when my head bandage. Nobody ever loved me" (Walker, 1983, p. 103). Meanwhile, Shug proves herself the bacon of light and love, she often shows her tender feelings through words, "I love you, Miss. Celie" (Walker, 1983, p. 103). With Shug's generosity, Celie has been provided with respect, recognition and strength.

\subsection{Maslow's Self-Actualizing Characteristics in Celie's Character}

Table 6. Celie's self-actualized traits of personality

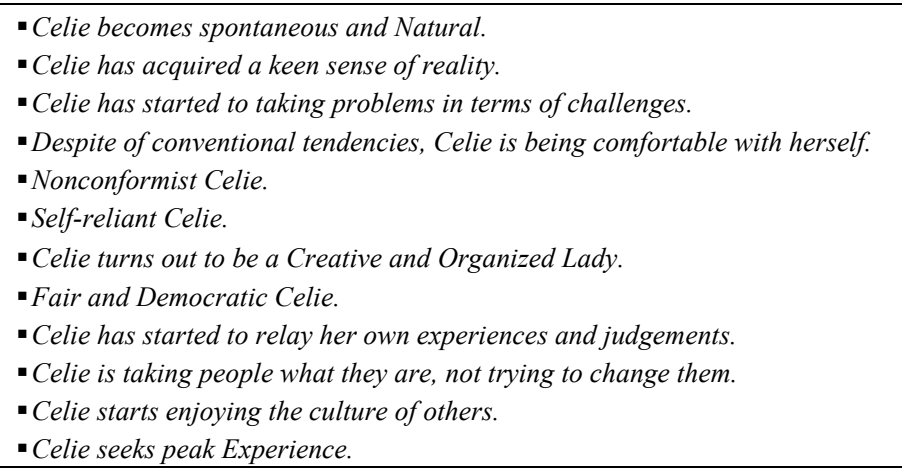

According to Maslow, (1954) "Self- Actualization is the position or a desire to get or acquire what a person really wants." Furthermore, Maslow's theory describes, "A Musician must make music, an artist must paint, a poet must write, what a man can be, he must be" (Maslow, 1954, p. 46).

\subsubsection{Spontaneous and Natural}

The first evidence of self-actualization occurs, timid and fragile Celie becomes spontaneous and free. She responds over unjustified conduct of Mr. Albert for hiding Nettie's letters. She anguishes and bursts before Shug, "how I 'm going keep from killing him" (Walker, 1983, p. 129). The utmost emerging characteristic of self-actualization has transmitted through her strong reaction.

\subsubsection{Keen Sense of Reality}

When Celie starts to acquire her self-actualizing characteristics, she attains the sense of reality simultaneously. She has become aware of surroundings instantly. She denies Shug for favoring M. Albert, declaring and demanding truth, "Mr. Albert not Christ, I'm not Christ" (Walker, 1983, p. 129). Celie is transforming from a cataphor to butterfly. Breaking the long-imposed silence on her personality. 
Celie has started taking problems for challenges. She peacefully contemplates and finds solution during complications. She often visualizes her children coming home. She hesitates for telling them their embarrassing birth truth, "I feel shame, more than love, to tell the truth" (Walker, 1983, p. 33). Later she gathers herself "anyway, as they alright here" (Walker, 1983, p. 133). She has prepared to face situation with the plan of adjustment as well. Once Celie wrote to Nettie and shared her experiences of visiting "pa". "For the first time in my life I wanted to see Pa." She has found out the truth of 'Pa' not being her real father (Walker, 1983, p. 173). She writes Nettie, "I don't write to God no more, I write to you" (Walker, 1983, p. 173). Celie has taken all decisions individually and independently. Being aware of real situations and becoming able to judge people and situations objectively has become an important acquired trait of Celie's personality.

\subsubsection{Nonconformist Celie}

Celie demonstrates the nonconformist turn. When Shug declares Mr. Albert, "Celie is coming Memphis with me" (Walker, 1983, p. 80), and Mr. Albert decisively glared, "Over my dead body" (Walker, 1983, p. 180). Rapidly, Celie proves she would never susceptible to any pressure. She scowled, "You low down dog, it's time to leave you can enter into the creation... and your dead body just a welcome mat I need" (Walker, 1983, p. 180). Not only verbally but also physically she defends herself. Mr. Albert reaches to slap her and in retort, Celie cuts his hand with knife. To all the other family members, it was an unexpected reaction by Celie. This incident evidences her a nonconformist being.

\subsubsection{Creative and Organized Celie}

Celie proves herself a creative mind person. In Memphis, she ponders, "how to make living (Walker, 1983, p. 192)? however she has already been working for "pants making". At first, she agrees having no idea of pant making, "I did not know what I was starting" (Walker, 1983 p. 191). But eventually, she made a perfect pair of pants. Later, she organizes her own business. Celie has confirmed herself as an innovative, talented and organized lady. Before entering into her peak experiences, Celie shares her joys with Nettie, "I am so happy, I got love, I got work, I got money, friends and time" (Walker, 1983, p. 191).

\subsubsection{Reliant on Own Experiences and Judgments}

When Mr. Albert probes, "whether the only reason for disliking her was being a man?" The self-reliant Celie shook with rage, "Man look like frog to me. No matter have you kiss' em, as far as I'm concern frogs is what they stay" (Walker, 1983, p. 230). Celie has never changed her judgment for men. She has vividly shown her disgust for them frequently. Even though, Mr. Albert starts behaving nicely to Celie, she feels the same animosity against menfolk.

Celie never believes Nettie has died, “I don't believe you dead. How can you be dead if I still feel you?" (Walker, 1983, p. 233). Mr. Albert fabricated lies regarding Nettie's death and spread false rumors about her children. She has never trusted anyone only relied in her own intuition.

\subsubsection{Accepting Others as They Are, Not Trying to Change People}

Initially, Celie gets distressed over the relationship of Shug with her new nineteen-year-old boyfriend "Germain". She feels her absence often. Since, she has been acquiring her self-actualizing characteristics, she accepts Shug's freedom and need for space. "Shug got a right over the world in whatever the company she chooses. Just because I love her don't take away none of her rights" (Walker, 1983, p. 244). Furthermore, "who am I to tell her to love" (Walker, 1983, p. 244). Her self-actualized personality has been reflected through her acceptance of Shug with all her truth. Celie has never imposed anything on Shug. Instead, she values her decisions and choices.

\subsubsection{Enjoying Others' Culture}

Celie deliberates Mr. Albert what Nettie tells about Africa. Celie has fondly discussed about African people and culture, "people in Africa try to wear what feel comfortable in the heat" (Walker, 1983, p. 246). In addition, "Men sew in Africa, too" (Walker, 1983, p. 247). Furthermore, she has also reflected on Olinka's perspective about "Adam", and the contrasting ideas between white and black men on the Adam and Eve folk. The whole conversation reveals an entirely different Celie. Mr. Albert gets amazed and surprised. Moreover, Celie discloses Olinka's misconception about their color, they believe white people are naked, "the word for naked is white, but since they are covered by colors they are notnaked (Walker, 1983, p. 240). She informs everything about African, their hate for whites, misconceptions on Adam and Eve and "Bible". Olinka has pronounced some strict stereotypes against "Adam" and "white". They have connected their beliefs to "bible" and showed abhor to all, who are different in color.

Celie replicates enough over Olinka, African cultural values and conventional mindsets. Eventually, she has been 
rewarded (first time from Mr. Albert), "It took me long enough to notice you such a good company" (Walker, 1983, p. 250). Mr. Albert admits and admires the new lease of Celie's personality.

\subsubsection{Comfortable with Oneself}

Finally, Celie shows another important distinctive of her self-actualizing self. She reflects, "I know I can live contentedly without Shug" (Walker, 1983, p. 257), she apprehends she could live without Shug. Moreover, Mr. Albert asks Celie to marry him second time, she instantly refuses. And, Shug informs her about arrival, "I be so calm, if she comes, I be happy if she doesn't. I be content. And then I figure this the lesson I was supposed to learn (Walker, 1983, p. 257). She has accepted life in the natural flow, with or without someone. She does not bother about anyone's presence. She remains calm and contented living peace and harmony.

\subsubsection{Celie's Peek Experience}

Maslow designates a "peek experience" by means of, "The feeling of great ecstasy, wonder and awe, the loss of placing in time and space with, finally, the conviction something extremely important and valuable had happened, so the subject is to some extent transformed and strengthened" (Walker, 1983, p. 56). Eventually, Celie meets her peek experience on July, the $4^{\text {th }}$, on the sudden arrival of Nettie and her Children. First, she experiences nous of awe and wonder, "by now my heart is in my mouth and I can't move" (Walker, 1983, p. 260). Simultaneously, she feels great ecstasy "I am so scared I don't know what to do feel like my mind stuck" (Walker, 1983, p. 260), she experiences to loss in the sense of placing "when Nettie foot come down. I almost die" (Walker, 1983, p. 260). Celie relishes the peek experience. With such savoring experience, Celie traces the self-actualization. Celie rejuvenates the sense of completion, with the everlasting experience of her journey. Celie achieves her ultimate desire to meet Nettie and her Children, her heart overwhelmed with happiness over her meeting of "peek experience' way to the journey of Self-actualization, "us so happy, ... I think this the youngest us ever felt" (Walker, 1983, p. 261).

\section{Conclusion}

Celie's character has been distorted by numerous dilemmatic situations. She has been severely adhered to her wellbeing supplies, leads to her security threats and its absence. She couldn't meet her esteem needs. Because, no one has endeavored to satisfy her affection and wellbeing needs, apart from Shug Avery. At the point, when Shug finishes her belonging needs, Celie finds ease to meet with her esteem needs and advances towards the higher-self.

Maslow's needs theory formulas a practical method to analyze the character's needs. Celie's personality gives significant information about the importance of gathering lower level needs, prior to higher goods. Her life was dormant when she didn't meet her security, belonging \& Esteem needs. But, when she starts relying on her true human magical potential, by expending her needs in the hierarchal order, she contacts Self-Actualization.

\section{References}

Banik. A. (2006). Diaspora and Maslow's hierarchy of needs with reference to the Mimic Men by V. S Naipaul. IJELLS, 4(4), 2278-0742. Retrieved from http://www.ijells.com/wp-content/uploads/2016/01/january-2016.pdf

Clewett, R. (n.d.) The Color Purple and the State of Literary Criticism. Retrieved from http://people.eku.edu/clewettr/colpur.htm

Essays, UK. (November 2013). Hierarchy of Needs in A Doll's House English Literature Essay. Retrieved from https://www.ukessays.com/essays/english-literature/hierarchy-of-needs-in-a-dolls-house-english-literature-e ssay.php?cref=

Gale. T. (2005). Psychologists and Their Theories for students (Kristine Krapp, ed., vol. 1, pp. 39-66). A.K Retrieved http://dlia.ir/Scientific/e_book/Philosophy_Psychology_Religion/Psychology/BF_1_990_Psychology_/000 275.pdf

Joyo, A., \& Memon, S. (2015). A Critical Analysis of 'Slum Child' By Bina Shah, Under the Marxist Theory of Reflectionism by Georg Lukacs. Proceedings of ADVED15 International Conference on Advances in Education and Social Sciences, 12-14 October 2015, Istanbul, Turkey. Retrieved from http://www.ocerint.org/adved15_epublications/papers/164.pdf

Kibin-essays (old English literature and Poetry) Beowulf. (n.d.). Maslow's theories of Hierarchy and self-actualization on the examples of literary characters Beowulf, Everyman and Macbeth. Retrieved from https://www.kibin.com/essay-examples/maslows-theories-of-hierarchy-and-self-actualization-on-the-examp 
les-of-literary-characters-beowulf-everyman-and-macbeth-YqEvmWno

Levin, R. (1993). The New Interdisciplinarity in Literary Criticism (pp. 13-45). After Poststructuralism: Interdisciplinarity and Literary Theory. Ed. Nancy Easterlin and Barbara Riebling.Evanston: Northwestern University Press.

Lewis, C. (2012). Cultivating Black Lesbian Shamelessness: Alice Walker's "The Color Purple". Rocky Mountain Review, 66(2), 158-175. https://doi.org/10.1353/rmr.2012.0027

Maslow, A. H. (1954). Motivation and personality. New York: Harper. https://doi.org/10.1111/j.1467-6494.1954.tb01136.x

Muhammad, Y. A. (2007). The Character of Neil Perry in Dead Poets Society Novel seen from Abraham Maslow's Hierarchy of Needs theory. Thesis. Jakarta. The English Letters Department Faculty of "Adab" and Humanities State Islamic University "Syarif Hidayatullah". Retrieved from http://respository.Uninjkt.ac.id/dspace/bitstrem/123456789/7535/1/MUHAMMAD\%20YANUAR\%20\%A RIFIN-FAH.pdf

Ross, D. W. (1988). Celie in the looking glass: The Desire for selfhood in The Color Purple. Modern Fiction Studies, 34(1), 69-84. https://doi.org/10.1353/mfs.0.0045

Sutich, A. J., \& Vich, M. A. (1969). Introduction. In A. J. Sutich \& M. A. Vich (Eds.), Readings in humanistic psychology (pp. 1-18). Free Press: New York.

Tembo, D. (2009). Self and The Community in Alice Walker's Color Purple. Dissertation. University of Zambi. Retrieved from http://dspace.unza.zm:8080/xmlui/bitstream/handle/123456789/1144/TemboDennis0001.PDF?sequence=1

Tyson, L. (2006). Critical theory today: A user friendly guide. New York: Routledge.

Wadehra. R. (2011). Slum Child and the Mahatma. Spectrum, Sunday. Retrieved from http://www.tribuneindia.com/2011/20110116/spectrum/book9.ht

Walker, A. (1983). Color Purple. London: Orion Books Limited.

Walsh, M. (1987). The Enchanted World of The Color Purple. Southern Quarterly, 25(2), 89-101.

\section{Copyrights}

Copyright for this article is retained by the author, with first publication rights granted to the journal.

This is an open-access article distributed under the terms and conditions of the Creative Commons Attribution license (http://creativecommons.org/licenses/by/4.0/). 